\title{
Leveraging large multi-center cohorts of Alzheimer Disease endophenotypes to understand the role of Klotho heterozygosity on disease risk
}

Muhammad Ali ${ }^{1,2}$, Yun Ju Sung ${ }^{1,2}$, Fengxian Wang ${ }^{1,2}$, Maria V. Fernández ${ }^{1,2}$, John C. Morris ${ }^{4,5}$, Anne M. Fagan ${ }^{4,5}$, Kaj Blennow ${ }^{6,7}$, Henrik Zetterberg ${ }^{6,7,8,9}$, Amanda Heslegrave ${ }^{8,9}$, Per M Johansson ${ }^{8,9,10}$, Johan Svensson ${ }^{11}$, Bengt Nellgård ${ }^{11}$, Alberto Lleo ${ }^{12}$, Daniel Alcolea ${ }^{12}$, Jordi Clarimon $^{12}$, Lorena Rami ${ }^{10}$, José Luis Molinuevo ${ }^{14,15}$, Marc Suárez-Calvet ${ }^{15,16,17}$, Estrella MorenasRodríguez $^{16,18}$, Gernot Kleinberger ${ }^{16,18}$, Christian Haass ${ }^{16,17,18}$, Michael Ewers ${ }^{19}$, the Alzheimer's Disease Neuroimaging Initiative (ADNI) ${ }^{*}$, Carlos Cruchaga ${ }^{1,2,3, \dagger}$.

${ }^{1}$ Department of Psychiatry, Washington University School of Medicine, 660 S. Euclid Ave. B8134, St. Louis, MO 63110, USA.

${ }^{2}$ Neurogenomics and Informatics Center, Washington University School of Medicine, $660 \mathrm{~S}$. Euclid Ave. B8134, St. Louis, MO 63110, USA.

${ }^{3}$ Hope Center for Neurological Disorders, Washington University School of Medicine, $660 \mathrm{~S}$. Euclid Ave. B8111, St. Louis, MO 63110, USA.

${ }^{4}$ Department of Neurology, Washington University School of Medicine, St Louis, Missouri, USA.

${ }^{5}$ Knight Alzheimer Disease Research Center, Washington University School of Medicine, St Louis, Missouri, USA.

${ }^{6}$ Department of Psychiatry and Neurochemistry, Institute of Neuroscience and Physiology, the Sahlgrenska Academy at the University of Gothenburg, Mölndal, Sweden.

${ }^{7}$ Clinical Neurochemistry Laboratory, Department of Neuroscience and Physiology, University of Gothenburg, Sahlgrenska University Hospital, Mölndal, Sweden.

${ }^{8}$ Department of Neurodegenerative Disease, UCL Institute of Neurology, Queen Square, London, UK.

${ }^{9}$ UK Dementia Research Institute at UCL, London, UK.

${ }^{10}$ Department of Anesthesiology and Intensive Care Medicine, Sahlgrenska University. Hospital, Mölndal, Sweden and Institute of Clinical Sciences, the Sahlgrenska Academy at the University of Gothenburg, Sweden.

${ }^{11}$ Department of Internal Medicine, Institute of Medicine, the Sahlgrenska Academy at the University of Gothenburg, Göteborg, Sweden.

${ }^{12}$ Neurology Dept. Hospital de la Santa Creu i Sant Pau. Sant Antoni Ma Claret 167. Barcelona 08025. Spain.

${ }^{13}$ IDIBAPS. Alzheimer's disease and other cognitive disorders unit, Neurology Service, ICN Hospital Clinic.

${ }^{14}$ Alzheimer's disease and other cognitive disorders unit, Neurology Service, ICN Hospital Clinic i Universitari. 
${ }^{15}$ BarcelonaBeta Brain Research Center, Pasqual Maragall Foundation. Barcelona, Spain.

${ }^{16}$ Biomedical Center (BMC), Biochemistry, Ludwig-Maximilians-Universität München, Munich, Germany.

${ }^{17}$ German Center for Neurodegenerative Diseases (DZNE), Munich, Germany.

${ }^{18}$ Munich Cluster for Systems Neurology (SyNergy), Munich, Germany.

${ }^{19}$ Institute for Stroke and Dementia Research, University Hospital, LMU, Munich, Germany.

* Data used in preparation of this article were obtained from the Alzheimer's Disease Neuroimaging Initiative (ADNI) database (adni.loni.usc.edu). As such, the investigators within the ADNI contributed to the design and implementation of ADNI and/or provide data but did not participate in analysis or writing of this report. A complete listing of $A D N I$ investigators can be found at:

http://adni.loni.usc.edu/wp-content/uploads/how_to_apply/ADNI_Acknowledgement_List.pdf

${ }^{\dagger}$ Author to whom correspondence should be addressed. 


\begin{abstract}
Two genetic variants (rs9536314 and rs9527025) in the Klotho gene, encoding a transmembrane protein, implicated on longevity and associated with brain resilience during normal aging, were recently shown to be associated with Alzheimer disease $(A D)$ risk in cognitively healthy individuals that are APOE4 carriers. Specifically, the individuals heterozygous for this variant (KL-SVHET+), showed lower risk of developing AD. Furthermore, a neuroprotective effect of KL-VS ${ }^{\mathrm{HET}+}$ has been suggested against amyloid burden for cognitively normal individuals. However, inconsistent associations and a smaller sample size of existing studies pose significant hurdles in drawing definitive conclusions. Here, we have performed a well-powered association analysis between ${\mathrm{KL}-V S^{\mathrm{HET}+}}$ and five different $\mathrm{AD}$ endophenotypes; brain amyloidosis measured by positron emission tomography (PET) scans $(n=5,541)$ or cerebrospinal fluid $A \beta$ levels (CSF; $n=5,093$ ), as well as biomarkers associated with tau pathology: the CSF Tau ( $n=5,127)$, phosphorylated Tau (pTau; $n=4,778$ ) and inflammation: CSF soluble triggering receptor expressed on myeloid cells 2 (sTREM2; $n=2,123$ ) levels. Our results found nominally significant associations of $\mathrm{KL}$ $\mathrm{VS}^{\mathrm{HET}+}$ status with biomarkers for brain amyloidosis (e.g. CSF A $\beta$ positivity; odds ratio [OR] = 0.67 [95\% Cl, 0.55-0.78], $\beta=0.72, P=0.007$ ) and tau pathology (e.g. biomarker negative for CSF Tau; $\mathrm{OR}=0.39$ [95\% Cl, 0.19-0.77], $\beta=-0.94, P=0.007$, and pTau; OR $=0.50$ [95\% Cl, 0.27-0.96], $\beta=-0.68, P=0.04)$ in elderly $(60-80$ years old) individuals that are cognitively normal and APOE4 carriers. Our work supports previous findings and suggests that the KL-VS ${ }^{\mathrm{HET}+}$ on a APOE4 genotype background may exert a protective effect by modulating the $A \beta$, Tau, and pTau burden and resulting cognitive decline in older controls susceptible to AD. The biological mechanism underlying APOE4 and $\mathrm{KL}-\mathrm{VS}^{\mathrm{HET}+}$ interaction and the neuroprotective effect of $\mathrm{KL}$-related pathways against amyloid accumulation may warrant future investigation as a target for preclinical pharmacological studies to explore novel AD drug targets.
\end{abstract}


medRxiv preprint doi: https://doi.org/10.1101/2021.10.07.21264646; this version posted October 10, 2021. The copyright holder for this preprint (which was not certified by peer review) is the author/funder, who has granted medRxiv a license to display the preprint in perpetuity.

All rights reserved. No reuse allowed without permission.

\section{Introduction}

Alzheimer disease (AD), the most common form of dementia, affects about $30 \%$ of those aged over 85 years [1]. AD is classified as a neurodegenerative disease, affecting the brain integrity and functioning, eventually resulting in a progressive deterioration of cognitive capabilities [2]. Besides aging, a strong genetic risk factor for developing $A D$ is the existence of epsilon 4 allele of the apolipoprotein E (APOE4) [3,4]. As such, subjects carrying APOE4 allele are significantly overrepresented among persons diagnosed with $A D$, in comparison to the non-carriers $[5,6]$. This particular genetic variant has been shown to be associated with cognitive decline [7] and reduced mean age at onset even within families with late onset AD [8]. Even among pre-symptomatic or cognitively normal subjects, carrying two copies of APOE4 allele (APOE4 homozygosity) has been reported to elevate the $A \beta$ deposition [9-12], an earlier age-related memory decline [13], and an increased incidence of conversion [9], in comparison to APOE4 heterozygotes and noncarriers. These evidences suggest that APOE4 genotype lies at the core of $A D$ pathophysiology, primarily due to its key role in cerebral $A \beta$ pathology. Therefore, the search for potential genetic factors that interact with APOE4 genotype to reduce A $\beta$ burden and eventually an individual's risk for developing $A D$ is crucial for halting the progression of disease and providing novel drug targets for an effective therapeutic intervention.

One such genetic factor that has been recently evaluated for its protective effect from developing $A D$ in individuals that are cognitively normal and APOE4 carriers is Klotho (KL) protein heterozygosity $[6,14,15] . \mathrm{KL}$ is a transmembrane protein, implicated as a longevity factor $[16,17]$ that promotes neuronal functions and brain resilience during aging [18-20]. In humans, two variants in the KL gene (rs9536314 for p.F352V and rs9527025 for p.C370S), that exist in a strong linkage disequilibrium, segregate together to form a functional haplotype called KL-VS. Interestingly, heterozygosity for the $\mathrm{KL}-\mathrm{VS}$ haplotype $\left(\mathrm{KL}^{-} \mathrm{VS}^{\mathrm{HET+}}\right)$ has been associated with higher level of $\mathrm{KL}$ abundance in the serum [18,21], which in turn has been reported to exhibit protective effects such as healthy brain aging and protective synaptic functions, in comparison to the individuals that are carrying two copies of KL-VS haplotype (KL-VS ${ }^{\mathrm{HET}^{-}}$) $[20,22]$. Even though $\mathrm{KL}-\mathrm{VS}^{\mathrm{HET}+}$ is associated with better cognitive health and longevity among those aging normally, there exist no clear indication of its involvement in protection against aging-associated neurodegenerative disorders, such as AD.

Identification of genetic risk factors for AD based on clinical diagnosis includes several challenges. As such, $A D$ diagnosis relies on the evidence of cognitive decline using standard cognitive tests that might be influenced by factors unrelated to disease e.g. anxiety, education, and general testtaking ability of the subject [23]. A complementary approach to the classical case-control studies is using intermediate phenotypes (endophenotypes) such as cerebrospinal fluid (CSF) biomarkers and $A \beta$ burden assessed by positron emission tomography (PET) scanning. Using brain endophenotypes that are objective and highly reproducible, has the ability to provide enough statistical power to identify AD genetic risk factors, novel associations, and understand their impact on the brain [23,24]. For example, by using brain endophenotypes, researchers have identified novel protective genetic variants in TMEM106B and MS4A genes, associated with high neuronal proportion in AD [25], and increased CSF soluble triggering receptor expressed on myeloid cells 2 (TREM2) concentrations with reduced AD risk, respectively [26]. 
medRxiv preprint doi: https://doi.org/10.1101/2021.10.07.21264646; this version posted October 10, 2021. The copyright holder for this preprint (which was not certified by peer review) is the author/funder, who has granted medRxiv a license to display the preprint in perpetuity.

All rights reserved. No reuse allowed without permission.

In the spectrum of AD pathology and different genetic factors that exert a protective effect in the context of disease onset and/or progression, KL-VS appears to be a compelling candidate due to its implication in promoting longevity and cognitive resilience during aging [18,20,22]. Interestingly, two recent studies aimed at accessing the protective effect of $\mathrm{KL}^{-} \mathrm{VS}^{\mathrm{HET}+}$ against $\mathrm{AD}$ in cognitively normal individuals [15,27], and provided contradictory evidence. The first study [15] focused on 309 late-middle-aged adults (mean age 61 years) and found KL-VS ${ }^{H E T+}$ to be associated with reduced $A \beta$ aggregation, suggesting its protective effect against APOE4-linked pathways to disease onset in AD. The second study [27] focused on 581 adults (mean age 71 years) and found no significant associations between $\mathrm{KL}^{-\mathrm{VS}^{\mathrm{HET}}+}$ and cognitive decline, independent of the APOE4 genotype, suggesting no modifying effect of $K L-V S^{H E T+}$ on $A \beta$ aggregation and APOE4-driven cognitive decline in preclinical AD. Furthermore, a recent largescale meta-analysis [6], focused on cognitively normal individuals in the age range of 60-80 years and revealed a $30 \%$ reduction in AD risk for subjects that are APOE4 carriers and KL-VS ${ }^{\mathrm{HET}}$. They also observed a significant association between $\mathrm{KL}-\mathrm{VS}^{\mathrm{HET}+}$ and higher A 342 in CSF (P-value 0.03) and lower $A \beta$ on PET scans (P-value 0.04), modulated by APOE4 status. Due to contradictory outcomes from the existing reports and their relatively small sample sizes, we aimed at performing a systematic evaluation of association between $\mathrm{KL}^{-V S^{\mathrm{HET}}+}$ and multiple wellestablished AD endophenotypes to check whether it has a protective effect on AD. Here, we have performed a well-powered association analysis between $\mathrm{KL}-\mathrm{VS}^{\mathrm{HET}+}$ and five different $\mathrm{AD}$ endophenotypes; A $\beta$ assessed by PET scans $(n=5,541)$ and CSF $(n=5,093)$, as well as the CSF Tau ( $n=5,127)$, phosphorylated Tau (pTau; $n=4,778)$ and TREM2 $(n=2,123)$. In line with previous studies, we performed APOE4- and age-stratified (60-80 years) analyses, to determine if there is any association between $\mathrm{KL}^{-V^{H E T+}}$ and $\mathrm{A} \beta$ aggregation that is modulated by APOE4 status. In addition, we also evaluated if there is any association between KL-VS ${ }^{\mathrm{HET}+}$ and other AD endophenotypes that include Tau, pTau, and TREM2 measured by CSF. Briefly, in the case of APEO4-carriers, we found significant associations between $\mathrm{KL}-\mathrm{VS}^{\mathrm{HET}+}$ and biomarkers for brain amyloidosis (CSF A $342 ; P$-value $=0.007$ ) and tau pathology (CSF Tau; $P$-value $=0.007$, and pTau; $P$-value $=0.04$ ). As evident from the observed $P$-values, the detected associations are nominally significant that would likely fail the multiple test correction, indicating the need of validating these findings in studies with even larger sample size for drawing definitive conclusion. Albeit nominally significant, these findings suggest that the combination of $\mathrm{KL}_{-} \mathrm{VS}^{\mathrm{HET}+}$ and APOE4 genotype exert a protective effect by modulating the CSF $A \beta$, Tau, and pTau burden and resulting cognitive decline in older controls susceptible to AD. 
medRxiv preprint doi: https://doi.org/10.1101/2021.10.07.21264646; this version posted October 10, 2021. The copyright holder for this preprint (which was not certified by peer review) is the author/funder, who has granted medRxiv a license to display the preprint in perpetuity.

All rights reserved. No reuse allowed without permission.

\section{Methods}

\section{Study samples and phenotype processing}

For this study, we collected data from 17 different AD-related cohorts with a total sample size of 9,526 (Table S1). We analyzed the association between KL-VS ${ }^{\mathrm{HET}+}$ and five different $\mathrm{AD}$ endophenotypes (Table 1) that served as biomarkers for brain amyloidosis (A $\beta$ levels assessed by amyloid-PET $[n=5,541]$ and A 42 measured from CSF $[n=5,093]$ ), tau pathology (Tau $[n=$ $5,127]$ and $\mathrm{pTau}[\mathrm{n}=4,778]$ from CSF), and inflammation-specific (sTREM2 levels from CSF [ $\mathrm{n}$ $=2,123]$ ). These subjects come from Memory and Aging Project (MAP), Alzheimer's Disease Neuroimaging Initiative (ADNI), BIOCARD, the Dominantly Inherited Alzheimer Network (DIAN), HB, Lleo, London, MOLI, Pau, Mayo Clinic (Mayo), SWEDEN, UPENN, UW, Progression Markers Initiative (PPMI), Anti-Amyloid Treatment in Asymptomatic Alzheimer's Disease (A4), and ADNI Department of Defense (ADNIDOD) studies. A part of data used in the preparation of this article was obtained from the ADNI database (adni.loni.usc.edu). ADNI was launched in 2003 as a public-private partnership, led by Principal Investigator Michael W. Weiner. Collection of genotype data, PET image processing, and CSF data processing for each cohort are described in detail in the respective studies $[10,11,25,26,28,29]$.

Briefly, subjects were included if they were diagnosed as cognitively normal or AD, based on the clinical assessments from the respective studies. Any subject that was missing information about the sex, age, KL-VS ${ }^{\mathrm{HET}+}$, APOE4 genotype, and genetic principal components (PCs), was excluded from the study. Following this rationale, we considered 3,725 cognitive normal individuals assessed by amyloid-PET and 1,030 cognitive normal individuals measured by CSF (AB42, Tau, pTau) and 639 individuals with CSF-TREM2 levels.

For each cohort, amyloid PET images were normalized to their reference cerebellar regions in order to obtain standardize uptake value ratios (SUVR) in a composite of cortical brain areas. The $z$-scores were calculated for each endophenotype using the mean and standard deviation (SD) units across each cohort and applied to the entire endophenotype.

All endophenotypes were also dichotomized as biomarker positive (case) or negative (control) using cutoffs defined for each endophenotype [11]. Defining biomarker positivity and negativity requires the selection of a cut-point at which to dichotomize. In order to dichotomize the scalar quantitative endophenotypes, we employed a gaussian mixture model (GMM) that relies on hierarchical model-based agglomerative clustering to get votes for defining a cut-point for dichotomization. We used Mclust function from "mclust" R package (version 5.4.6) for dichotomizing all endophenotype.

\section{Genotyping, quality checks, imputation, and population structure}

We applied stringent quality control (QC) steps to process the genotyping array and sequencing data. We used the threshold of $98 \%$ for removing single nucleotide polymorphisms (SNPs) and individuals with low call rate. Autosomal SNPs that were not in the Hardy-Weinberg equilibrium $\left(P<1 \times 10^{-6}\right)$ were also removed. Subject duplication and relatedness was estimated from identityby-descent (IBD) analysis carried out in Plink version 1.9 [30]. In case of related subjects (Pihat 
medRxiv preprint doi: https://doi.org/10.1101/2021.10.07.21264646; this version posted October 10, 2021. The copyright holder for this preprint (which was not certified by peer review) is the author/funder, who has granted medRxiv a license to display the preprint in perpetuity.

All rights reserved. No reuse allowed without permission.

20.25), the sample from MAP or with a higher number of variants that passed the QC was prioritized. For phasing and imputation, we used The 1000 Genomes Project Phase 3 data (October 2014), SHAPEIT v2.r837 [31], and IMPUTE2 v2.3.2 [32]. We used impute probability score $<0.90$ and $\geq 0.90$ as thresholds for missing and fully observed individual genotypes, respectively. Genotyped and imputed variants with MAF $<0.02$ or IMPUTE2 information score < 0.30 were discarded. Principle component analysis (PCA) was performed on the genotype data to obtain genetic PCs that capture population substructure (supplementary figure S2). In order to obtain the largest and most homogeneous pool of population, only European individuals were considered (supplementary figure S3) for the subsequent statistical analyses.

\section{Statistical Analyses}

Statistical analyses and data visualization were performed in Plink version 1.9 [30] and $R$ version 3.5.2 [33]. We performed association analyses of $\mathrm{KL}^{-\mathrm{VS}^{\mathrm{HET}}+}$ status with different $\mathrm{AD}$ endophenotypes from PET scan $(A \beta)$ and CSF (Aß42, Tau, pTau, and TREM2). The associations between the biomarker positivity and $\mathrm{KL}-\mathrm{VS}^{\mathrm{HET}+}$ were tested using general linear model (GLM). The implementation of GLM from the base R [33] "stats" package was used for the evaluation of association and the outcomes measurements were adjusted for sex, age, and first three genetic PCs. For the A $\beta$ levels measured by PET scan, we considered the age at scan and in the case of endophenotype levels measured by CSF, we considered subject age when lumbar puncture was performed. Furthermore, associations were evaluated across three different strata, (1) all subjects (AD and controls), (2) subjects aged 60 to 80 years (AD and controls), and (3) only control subjects aged 60 to 80 years. All association analyses were stratified by APOE4 status, APOE4 carriers (APOE- 24, 34, 42, 43, and 44) and APOE4 non-carriers (APOE- 22, 23, 32, and 33). Associations were deemed significant at a threshold of $P$-value $<0.05$. A schematic overview of conducted analyses and used datasets is provided in Figure 1. 
medRxiv preprint doi: https://doi.org/10.1101/2021.10.07.21264646; this version posted October 10, 2021. The copyright holder for this preprint (which was not certified by peer review) is the author/funder, who has granted medRxiv a license to display the preprint in perpetuity.

All rights reserved. No reuse allowed without permission.

\section{Results}

The aim of this study was to determine whether there is a significant association between KL$\mathrm{VS}^{\mathrm{HET}+}$ and $\mathrm{AD}$ endophenotypes in cognitively normal individuals that are APOE4-carriers. To accomplish this goal, we analyzed genetic data and five different AD endophenotypes from 9,526 individuals obtained through 17 different AD-related cohorts. In line with existing studies [6,15], our findings validate the protective effect of $\mathrm{KL}^{-V S^{\mathrm{HET}}+}$ against $\mathrm{AD}$ in healthy individuals that are APOE4 carriers.

\section{Association between KL-VS ${ }^{\mathrm{HET}+}$ status and brain amyloidosis measured by PET scan and CSF}

We evaluated the association of $\mathrm{KL}^{-} \mathrm{VS}^{\mathrm{HET}+}$ status against $\mathrm{A} \beta$ levels measured by the PET scan and CSF for 5,541 and 5,093 subjects, respectively (Table 1). Although associations were evaluated for three different age ranges (Table S2), our main focus was control subjects that are 60 to 80 years old (Table 2). We focused on this age range for being consistent with existing studies that report a pronounced effect of APOE4 positivity in AD between age 60 to 80 years in

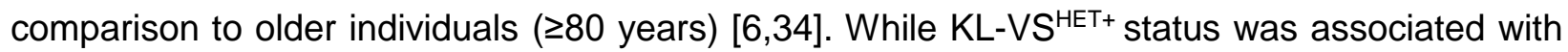
decreased levels of $A \beta$ positivity observed through the PET scan, there was no significant association found across any age group or APOE4 stratification (Table S2). On the other hand, we found a significant association between $\mathrm{KL}-\mathrm{VS}^{\mathrm{HET}}{ }^{\mathrm{H}}$ status and CSF A $\beta$ biomarker positivity in cognitively normal APOE4+ individuals that are 60 to 80 years old (Table 2 ; OR $=0.67[95 \% \mathrm{Cl}$, $0.55-0.78], \quad \beta=0.72, P=0.007)$. We also observed a significant association for APOE4 noncarriers, however, the effect size and the strength of the association was lower in this group (OR $=0.61[95 \% \mathrm{Cl}, 0.51-0.70], \beta=0.46, P=0.03$ ) than the APOE4 carriers (Table 2). Taken together, we were able to replicate the previously reported associative findings [6,34] between increased $\mathrm{A} \beta \mathrm{CSF}$ levels and $\mathrm{KL}-\mathrm{VS}^{\mathrm{HET}+}$ in a larger sample group.

\section{APOE4-related alteration in tau pathology varies by $\mathrm{KL}^{-V}{ }^{\mathrm{HET}+}$ status}

Similar to $A \beta$ association analyses, we also determined if there was an age- and APOE4dependent association of ${\mathrm{KL}-V S^{\mathrm{HET}}}^{+}$status with dichotomized CSF Tau and pTau levels. In the age range of 60 to 80 years, we observed significant association between KL-VS ${ }^{\mathrm{HET}+}$ status and CSF Tau (OR = 0.39 [95\% Cl, 0.20-0.77], $P=0.007$ ), and pTau (OR = 0.50 [95\% Cl, 0.27-0.96], $P=0.04)$ levels in elderly (60-80) cognitive normal APOE4+ participants (Table 2). In both cases, the $\mathrm{KL}-\mathrm{VS}^{\mathrm{HET}+}$ was associated with being biomarker negative (e.g., lower CSF Tau/pTau levels which are associated with lower AD risk ( $\beta=-0.94$ and -0.68 for Tau and pTau, respectively). Regarding the effect size, we observed an almost 6-fold decrease for both Tau and pTau levels in APOE4 carriers as compared to the non-carriers, suggestive of a more pronounced protective effect for subjects carrying one copy of KL-VS haplotype. As expected, a consistent negative association was observed for both modalities when effect sizes were represented in the form of a Forest plot (Figure 2). While we observed a consistent effect of $\mathrm{KL}^{-\mathrm{VS}}{ }^{\mathrm{HET}+}$ on tau pathology biomarker negativity for controls subjects that are APOE4 non-carriers $(\beta=-0.16$ and -0.11 for Tau and pTau, respectively), the association was not deemed significant in this stratum $(P=0.49$ and 0.61 for Tau and pTau, respectively). 
medRxiv preprint doi: https://doi.org/10.1101/2021.10.07.21264646; this version posted October 10, 2021. The copyright holder for this preprint (which was not certified by peer review) is the author/funder, who has granted medRxiv a license to display the preprint in perpetuity.

All rights reserved. No reuse allowed without permission.

\section{Direct effect of KL-VS ${ }^{\mathrm{HET}+}$ status on inflammation-specific biomarker}

For TREM2 CSF levels, we did not observe any significant association between this inflammationspecific biomarker and $\mathrm{KL}-\mathrm{VS}^{\mathrm{HET}+}$ status across any subject stratification, regardless of the age group and APOE4 status. Nevertheless, for control subjects aged 60 to 80 years, we observed that $\mathrm{KL}-\mathrm{VS}^{\mathrm{HET}+}$ status is associated with increased TREM2 CSF levels, which represents the positivity of inflammation-specific biomarker, but association was not deemed significant in APOE4 carriers $(\mathrm{OR}=1.08[95 \% \mathrm{Cl}, 0.58-2], \beta=0.08, P=0.80)$ as well as non-carriers $(\mathrm{OR}=$ 1.20 [95\% Cl, 0.77-1.86], $\beta=0.18, P=0.43$ ). These findings suggest the protective effect of $\mathrm{KL}$ $\mathrm{VS}^{\mathrm{HET}+}$ status by modulating the CSF TREM2 levels as existing literature has also associated increased CSF TREM2 levels with lower AD risk and slower progression [26,29].

\section{Sensitivity analysis result: Robustness of association between $\mathrm{KL}^{-V S^{\mathrm{HET}+}}$ status and brain amyloidosis to the APOE4 status, age, and sex}

In order to estimate whether association between $\mathrm{KL}-\mathrm{VS}^{\mathrm{HET}+}$ and amyloidosis are robust to uneven sample size of APOE4 carriers and non-carriers as well as differences in the sex and age of the participants, the association analysis was repeated with same number of APOE4 carriers ( $\mathrm{N}=$ 308) and non-carriers that are age- and sex-matched. As in the full-sample analyses for control subjects aged 60 to 80, the age-, sex-, and APOE4-group matched sample analyses revealed that, for $\mathrm{KL}-\mathrm{VS}^{\mathrm{HET}+}$, APOE4 status was consistently associated with CSF A $\beta$ biomarker positivity $(\mathrm{OR}=0.68$ [95\% Cl, 0.56-0.78], $\beta=0.75, P=0.005$; Table S3). In accordance with our findings from full-sample analysis, we also observed a significant association in case of APOE4 noncarriers, however, the effect size and the strength of the association was also lower in this group $(\mathrm{OR}=0.69$ [95\% Cl, 0.51-0.79], $\beta=0.70, P=0.034$ ) than the APOE4 carriers. Moreover, similar trends were observed in the case of amyloid imaging, CSF Tau, pTau, and TREM2 in age- and sex-matched as well as the full-sample analyses for control subjects aged 60 to 80 (Table S3). We have observed that correcting for class imbalance of APOE4-carriers and non-carriers as well as for males and females of same age, the direction of effect remains the same for each endophenotype, however, strength of association becomes more profound (lower p-values). Taken together, these results suggest that observed associations between $\mathrm{KL}$ heterozygous control individuals and different AD endophenotypes is independent of the distribution of APOE4 carriage status, age, and sex of participants.

\section{Cognitively normal subjects (aged 60 to 80 ) drive association between KL-VS ${ }^{\mathrm{HET}+}$ status and AD endophenotypes}

We also conducted an APOE4-stratified association analyses between $\mathrm{KL}^{-} \mathrm{VS}^{\mathrm{HET}}+$ status and biomarkers for brain amyloidosis (A $\beta$ from PET and CSF), tau pathology (CSF Tau and pTau), and inflammation (CSF TREM2) for all participants, regardless of their age and case-control status, and no significant association was observed in any of the five endophenotypes (Table S2). Similarly, we also performed the same analyses for elderly samples that are 60-80 years old, regardless of their case-control status, and even in that case no significant association was 
medRxiv preprint doi: https://doi.org/10.1101/2021.10.07.21264646; this version posted October 10, 2021. The copyright holder for this preprint (which was not certified by peer review) is the author/funder, who has granted medRxiv a license to display the preprint in perpetuity.

All rights reserved. No reuse allowed without permission.

detected across any endophenotype (Table S2). Nevertheless, it was interesting to see how the effects became apparent when we stratified the participants to the age range $60-80$ and considered only the cognitively normal subjects, as in that case a significant association was detected between $\mathrm{KL}-\mathrm{VS}^{\mathrm{HET}+}$ status and CSF A $\beta$, Tau, and pTau levels (Table S2). Notably, these findings suggest that the detected nominally significant associations were mainly driven by the control participants that are 60 to 80 years old. 
medRxiv preprint doi: https://doi.org/10.1101/2021.10.07.21264646; this version posted October 10, 2021. The copyright holder for this preprint (which was not certified by peer review) is the author/funder, who has granted medRxiv a license to display the preprint in perpetuity.

All rights reserved. No reuse allowed without permission.

\section{Discussion}

The role of Klotho protein as a longevity factor is widely recognized [16,17]. There has been an increasing amount of evidence supporting the relationship between $\mathrm{KL}^{-} \mathrm{VS}^{\mathrm{HET}}{ }^{+}$and preserved brain integrity and cognitive performance during normal aging [18-20]. In this study, we examined the association of $\mathrm{KL}-\mathrm{VS} \mathrm{S}^{\mathrm{HET}+}$ status with five different $\mathrm{AD}$-associated endophenotypes assessed from CSF biomarkers (A, Tau, pTau, TREM2) and PET scans (Aß). Specifically, we checked for association between $\mathrm{KL}_{-} \mathrm{VS}^{\mathrm{HET}+}$ status and biomarkers for brain amyloidosis (A $\beta$ levels measured from CSF and amyloid PET) and neurodegeneration (CSF Tau and pTau). To our knowledge, we have analyzed the largest sample size of $A D$ endophenotypic data for evaluating its association with $\mathrm{KL}-\mathrm{VS}^{\mathrm{HET}}{ }^{+}$, that is instrumental to discern the potential protective effect of this heterozygous genetic variant for AD in control APOE4 carriers. Our results showed that $\mathrm{KL}-\mathrm{VS}^{\mathrm{HET}}{ }^{\mathrm{T}}$ status was associated with CSF $A \beta$ and Tau/pTau biomarker negativity in individuals that are cognitively normal APOE4 carriers within age range of 60 to 80 years, suggesting that KL-VS ${ }^{\mathrm{HET}+}$ status reduces the risk of $A D$ in APOE4 carriers by lowering the AD pathology burden $[6,34]$.

We were able to replicate the findings by Belloy et al [6]; that is, $\mathrm{KL}-\mathrm{VS}{ }^{\mathrm{HET}+}$ status was significantly associated with increased CSF $A \beta$ levels (A $\beta$ biomarker positivity) for control subjects aged 60 to 80 years that are APOE4 carriers $(\mathrm{OR}=0.67[95 \% \mathrm{Cl}, 0.55-0.78$ ], $\beta=0.72, \mathrm{P}=0.007)$. This association was also significant in case of APOE4 non-carriers $(\mathrm{OR}=0.61$ [95\% $\mathrm{Cl}, 0.51-0.70$ ], $\beta=0.46, P=0.03)$, however, the effect and significance was lower suggesting a stronger protective interaction between APOE4 carriers and $\mathrm{KL}^{-V_{S}}{ }^{\mathrm{HET}+}$ status (Table 2). Although, no significant association is observed in the case of $A \beta$ from $P E T$, the detected negative association is suggesting the protective effect of $\mathrm{KL}-\mathrm{VS}^{\mathrm{HET}}+$ by reducing the $A \beta$ deposition, contrary to its higher levels that are found to be closely related to $A \beta$ deposition in neuritic plaques [35] - $a$ hallmark of AD. Discordance in A $\beta$ PET and CSF biomarkers has already been shown to have important consequences for their application in inspectional, clinical, and trial settings [36]. For example, a previous study investigating longitudinal differences in cognition between participants without dementia with different CSF and PET profiles found no memory decline in concordantnegative (CSF-/PET-) and discordant (CSF+/PET-) groups, in contrast to the concordantpositive (CSF+/PET+) group that deteriorated over time [37]. Furthermore, it is highly likely that observed discordance between $A \beta$ levels from PET and CSF is because changes in CSF A $\beta$ levels occur before detectable alterations in amyloid PET during preclinical stages of AD. Palmqvist et al [36] reported similar results, when they analyzed 437 non-demented subjects from $A D N I$ that had $A \beta$ levels from PET scans and CSF, showing that CSF A $\beta$ levels becomes abnormal in the earliest stages of AD, before amyloid PET and before neurodegeneration starts

We also investigated whether $\mathrm{KL}-\mathrm{VS}^{\mathrm{HET}+}$ status is significantly associated with Tau and pTau burden assessed from CSF. We found that $\mathrm{KL}_{\mathrm{V}} \mathrm{VS}{ }^{\mathrm{HET}+}$ status was significantly associated with decreased Tau (OR $=0.39$ [95\% Cl, 0.20-0.77], $\beta=-0.94, P=0.007$ ) and pTau (OR $=0.50[95 \%$ $\mathrm{Cl}, 0.27-0.96], \beta=-0.68, P=0.04$ ) levels (CSF Tau/pTau biomarker negativity) in subjects that are APOE4 carriers and 60 to 80 years old. Interestingly, in the case of APOE4 non-carriers, albeit having the similar negative trend, the associations were not significant for both Tau (OR $=0.85$ [95\% Cl, 0.54-1.35], $\beta=-0.16, P=0.49$ ) and pTau (OR $=0.89[95 \% \mathrm{Cl}, 0.57-1.39], \beta=-0.11, P$ $=0.61$ ). This indicates that $\mathrm{KL} \mathrm{VS}^{\mathrm{HET}+}$ status interaction with pathological aspects of $\mathrm{AD}$ are more profound in APOE4 carriers, such as $A \beta$ and Tau accumulation during the pre-clinical phase of 
medRxiv preprint doi: https://doi.org/10.1101/2021.10.07.21264646; this version posted October 10, 2021. The copyright holder for this preprint (which was not certified by peer review) is the author/funder, who has granted medRxiv a license to display the preprint in perpetuity. All rights reserved. No reuse allowed without permission.

the disease [38,39]. Indeed, previous studies have also reported a significant association between $\mathrm{KL}-\mathrm{VS}$ heterozygosity and reduced tau accumulation and lower memory impairment in elderly humans at risk of AD dementia [40,41]. However, in a mouse model of $A D$ that was used to examine the neuroprotective effects of Klotho protein against neuronal damage associated with oxidative stress and neurodegeneration, no changes in Tau phosphorylation were observed in the presence of Klotho [42]. Unlike Tau and pTau association with KL-VS ${ }^{\mathrm{HET}+}$ status, we observed a positive association in the case of CSF levels of soluble TREM2 (inflammation-specific biomarker). However, the observed increase in the CSF TREM2 levels was not significantly associated with $\mathrm{KL}-\mathrm{VS}^{\mathrm{HET}+}$ status for both APOE carriers (OR $=1.08[95 \% \mathrm{Cl}, 0.59-2], \beta=0.08$, $P=0.80)$ and non-carriers $(\mathrm{OR}=1.20[95 \% \mathrm{Cl}, 0.77-1.86], \beta=0.18, P=0.43)$. Interestingly, recent studies $[26,29]$ have shown that higher TREM2 levels are associated with lower AD risk and slower progression. Therefore, the observed positive association suggests that the protective effect of the KL-VS ${ }^{\mathrm{HET}+}$ might be mediated by higher CSF TREM2 levels. However, this hypothesis will need to be validated in studies with larger sample size for CSF TREM2 levels.

Taken together, the observed significant associations between KL-VS ${ }^{\mathrm{HET}+}$ status and biomarkers for brain amyloidosis (CSF A $\beta$ positivity) and neurodegeneration (CSF Tau and pTau negativity) are suggestive of neuroprotective effect of $\mathrm{KL}-\mathrm{VS}^{\mathrm{HET}+}$ against age-related biomarker, biomolecular, and cognitive alterations that confer risk for $A D$. Our results further strengthen the findings by a recent meta-analysis including 25 independent studies, showing that APOE4 carriers who were also $\mathrm{KL}_{-} \mathrm{VS}^{\mathrm{HET}+}$, were at a reduced risk for the combined outcome of conversion to mild cognitive impairment (MCl) or AD [6].

Notably, we assessed the associations between $\mathrm{KL}-\mathrm{VS} \mathrm{SET}^{\mathrm{HE}}$ status and $\mathrm{AD}$ endophenotypes across three age strata; all of the subjects (AD and controls), only subjects aged 60 to 80 years (AD and controls), and only control subjects aged 60 to 80 years (Table S2). Owing to a higher genetic risk for AD attributable to APOE4 in individuals that are 60 to 80 years old [43-45] and an existing study that hypothesized protective association of $\mathrm{KL}^{-V \mathrm{SET}^{\mathrm{H}}}$ status to be strongest in APOE4 carriers who are 60 to 80 years old [6], the focus of the current study was also at this particular age range. Although we observed similar associative trends most of the time, it was interesting to see how the effects became apparent when stratifying the cognitively normal subjects to the age range of 60 to 80 years. In all of the cases, no significant associations were observed between $\mathrm{KL}_{-} \mathrm{VS}^{\mathrm{HET}+}$ status and $\mathrm{AD}$ endophenotypes while considering all of the AD and control subjects, or all of the $A D$ and control subjects within age range of 60-80. However, pronounced effects and associations were apparent for $A \beta$, Tau, and PTau levels from CSF, while considering control individuals that are APOE4 carriers and $\mathrm{KL}^{-} \mathrm{VS}^{\mathrm{HET}}$. These findings suggest that the control group aged 60 to 80 years mainly drove the outcome in our analyses, further strengthening the existing hypothesis that KL-VS heterozygous genotype is favorable for survival in older people as compared to the young adults [46]. Importantly, we also observed that associations between $\mathrm{KL}$ heterozygous control individuals and different $A D$ endophenotypes are robust to uneven sample size of APOE4 carriers and non-carriers as well as differences in the sex and age of the participants (Table S3). Although, the observed findings are in line with our initial hypothesis and confirming existing literature [6,34], the detected associations are nominally significant that would likely fail the multiple test correction due to limited sample size. Therefore, additional studies are required to investigate the associations between $\mathrm{KL}^{-V S^{\mathrm{HET}}}{ }^{+}$and $\mathrm{AD}$ endophenotypes with relatively larger sample size to draw definitive conclusions. 
medRxiv preprint doi: https://doi.org/10.1101/2021.10.07.21264646; this version posted October 10, 2021. The copyright holder for this preprint (which was not certified by peer review) is the author/funder, who has granted medRxiv a license to display the preprint in perpetuity.

All rights reserved. No reuse allowed without permission.

The exact mechanism behind $\mathrm{KL}-\mathrm{VS}^{\mathrm{HET}}+$ interaction with APOE4 and modulation of $\mathrm{A} \beta$, Tau, and pTau burden is yet unknown. However, it is logical to presume that KL-VS ${ }^{\mathrm{HET}+}$ may confer resilience by increasing the serum level of circulating Klotho protein [18,21] or by changing its function. In animal mouse models, elevated klotho levels have led to an extended lifespan [17], enhanced cognition [19] and increased resilience to AD-related toxicity [47]. Other studies in humans, indicated that $\mathrm{KL}-\mathrm{VS}^{\mathrm{HET}}{ }^{+}$status has protective effects against brain aging and cognitive decline [21,46], suggestive of its protective association against AD. Our findings also suggest that middle-aged APOE4 carriers that are $\mathrm{KL}^{-V S^{\mathrm{HET}}}{ }^{+}$might be biologically younger than those who are APOE4 non-carriers and $\mathrm{KL}-\mathrm{VS}^{\mathrm{HET}}{ }^{\mathrm{H}}$, and thus show resilience to age-induced cognitive and tau changes. Interestingly, we have observed an age-specific association between $\mathrm{KL}_{-} \mathrm{VS}{ }^{\mathrm{HET}+}$ and $A D$ endophenotypes, which is in line with existing studies reporting a specific time window for the effect of KL-VS polymorphism [20,46].

To conclude, our work contribute to the existing state of the literature by demonstrating that the protective effects of $\mathrm{KL}_{-\mathrm{VS}}{ }^{\mathrm{HET}+}$ extend to age-related $\mathrm{A} \beta$, Tau, and pTau burden and deficits in memory and executive function in control APOE4 carriers susceptible for AD. One promising research avenue for the future studies could be to assess whether Klotho protein levels in the CSF or serum of individuals associate with measures of AD and preclinical disease. 
medRxiv preprint doi: https://doi.org/10.1101/2021.10.07.21264646; this version posted October 10, 2021. The copyright holder for this preprint (which was not certified by peer review) is the author/funder, who has granted medRxiv a license to display the preprint in perpetuity.

All rights reserved. No reuse allowed without permission.

\section{Acknowledgements}

ADNI acknowledgement: Data collection and sharing for this project was funded by the Alzheimer's Disease Neuroimaging Initiative (ADNI) (National Institutes of Health Grant U01 AG024904) and DOD ADNI (Department of Defense award number W81XWH-12-2-0012). ADNI is funded by the National Institute on Aging, the National Institute of Biomedical Imaging and Bioengineering, and through generous contributions from the following: AbbVie, Alzheimer's Association; Alzheimer's Drug Discovery Foundation; Araclon Biotech; BioClinica, Inc.; Biogen; Bristol-Myers Squibb Company; CereSpir, Inc.; Cogstate; Eisai Inc.; Elan Pharmaceuticals, Inc.; Eli Lilly and Company; Eurolmmun; F. Hoffmann-La Roche Ltd and its affiliated company Genentech, Inc.; Fujirebio; GE Healthcare; IXICO Ltd.; Janssen Alzheimer Immunotherapy Research \& Development, LLC.; Johnson \& Johnson Pharmaceutical Research \& Development LLC.; Lumosity; Lundbeck; Merck \& Co., Inc.; Meso Scale Diagnostics, LLC.; NeuroRx Research; Neurotrack Technologies; Novartis Pharmaceuticals Corporation; Pfizer Inc.; Piramal Imaging; Servier; Takeda Pharmaceutical Company; and Transition Therapeutics. The Canadian Institutes of Health Research is providing funds to support ADNI clinical sites in Canada. Private sector contributions are facilitated by the Foundation for the National Institutes of Health (www.fnih.org). The grantee organization is the Northern California Institute for Research and Education, and the study is coordinated by the Alzheimer's Therapeutic Research Institute at the University of Southern California. ADNI data are disseminated by the Laboratory for Neuro Imaging at the University of Southern California. HZ is a Wallenberg Scholar supported by grants from the Swedish Research Council (\#2018-02532), the European Research Council (\#681712), Swedish State Support for Clinical Research (\#ALFGBG-720931), the Alzheimer Drug Discovery Foundation (ADDF), USA (\#201809-2016862), the AD Strategic Fund and the Alzheimer's Association (\#ADSF-21-831376-C, \#ADSF-21-831381-C and \#ADSF-21-831377-C), the Olav Thon Foundation, the Erling-Persson Family Foundation, Stiftelsen för Gamla Tjänarinnor, Hjärnfonden, Sweden (\#FO2019-0228), the European Union's Horizon 2020 research and innovation programme under the Marie Skłodowska-Curie grant agreement No 860197 (MIRIADE), and the UK Dementia Research Institute at UCL.

KB is supported by the Swedish Research Council (\#2017-00915), the Alzheimer Drug Discovery Foundation (ADDF), USA (\#RDAPB-201809-2016615), the Swedish Alzheimer Foundation (\#AF742881), Hjärnfonden, Sweden (\#FO2017-0243), the Swedish state under the agreement between the Swedish government and the County Councils, the ALF-agreement (\#ALFGBG715986), the European Union Joint Program for Neurodegenerative Disorders (JPND2019-466236), the National Institute of Health (NIH), USA, (grant \#1R01AG068398-01), and the Alzheimer's Association 2021 Zenith Award (ZEN-21-848495).

Conflicts of interest:

$\mathrm{HZ}$ has served at scientific advisory boards and/or as a consultant for Abbvie, Alector, Eisai, Denali, Roche, Wave, Samumed, Siemens Healthineers, Pinteon Therapeutics, Nervgen, AZTherapies, CogRx, and Red Abbey Labs, has given lectures in symposia sponsored by Cellectricon, Fujirebio, Alzecure and Biogen, and is a co-founder of Brain Biomarker Solutions in Gothenburg AB (BBS), which is a part of the GU Ventures Incubator Program. 
medRxiv preprint doi: https://doi.org/10.1101/2021.10.07.21264646; this version posted October 10, 2021. The copyright holder for this preprint (which was not certified by peer review) is the author/funder, who has granted medRxiv a license to display the preprint in perpetuity.

All rights reserved. No reuse allowed without permission.

KB has served as a consultant, at advisory boards, or at data monitoring committees for Abcam, Axon, Biogen, JOMDD/Shimadzu. Julius Clinical, Lilly, MagQu, Novartis, Prothena, Roche Diagnostics, and Siemens Healthineers, and is a co-founder of Brain Biomarker Solutions in Gothenburg AB (BBS), which is a part of the GU Ventures Incubator Program, all unrelated to the work presented in this paper. 
medRxiv preprint doi: https://doi.org/10.1101/2021.10.07.21264646; this version posted October 10, 2021. The copyright holder for this preprint (which was not certified by peer review) is the author/funder, who has granted medRxiv a license to display the preprint in perpetuity. All rights reserved. No reuse allowed without permission.

References:

1. Ferri CP, Prince M, Brayne C, Brodaty H, Fratiglioni L, Ganguli M, et al. Global prevalence of dementia: A Delphi consensus study. Lancet. 2005. doi:10.1016/S01406736(05)67889-0

2. Budson AE, Solomon PR. New diagnostic criteria for Alzheimer's disease and mild cognitive impairment for the practical neurologist. Practical Neurology. 2012. doi:10.1136/practneurol-2011-000145

3. Roses AD. Apolipoprotein E alleles as risk factors in Alzheimer's disease. Annual Review of Medicine. 1996. doi:10.1146/annurev.med.47.1.387

4. Brousseau T, Legrain S, Berr C, Gourlet V, Vidal O, Amouyel P. Confirmation of the epsilon 4 allele of the apolipoprotein $\mathrm{E}$ gene as a risk factor for late-onset Alzheimer's disease. Neurology. 1994;44: 342-344. doi:10.1212/wnl.44.2.342

5. Polvikoski T, Sulkava R, Haltia M, Kainulainen K, Vuorio A, Verkkoniemi A, et al. Apolipoprotein E, Dementia, and Cortical Deposition of $\beta$-Amyloid Protein. N Engl J Med. 1995. doi:10.1056/nejm199511093331902

6. Belloy ME, Napolioni V, Han SS, Le Guen Y, Greicius MD. Association of Klotho -VS Heterozygosity with Risk of Alzheimer Disease in Individuals Who Carry APOE4. JAMA Neurol. 2020. doi:10.1001/jamaneurol.2020.0414

7. Cosentino S, Scarmeas N, Helzner E, Glymour MM, Brandt J, Albert M, et al. APOE $\varepsilon 4$ allele predicts faster cognitive decline in mild Alzheimer disease. Neurology. 2008. doi:10.1212/01.wnl.0000304038.37421.cc

8. Corder EH, Saunders AM, Strittmatter WJ, Schmechel DE, Gaskell PC, Small GW, et al. Gene dose of apolipoprotein E type 4 allele and the risk of Alzheimer's disease in late onset families. Science (80- ). 1993. doi:10.1126/science.8346443

9. Vlassenko AG, Mintun MA, Xiong C, Sheline YI, Goate AM, Benzinger TLS, et al. Amyloid-beta plaque growth in cognitively normal adults: Longitudinal [ 11C]Pittsburgh compound B data. Ann Neurol. 2011. doi:10.1002/ana.22608

10. Maxwell TJ, Corcoran C, Del-Aguila JL, Budde JP, Deming Y, Cruchaga C, et al. Genome-wide association study for variants that modulate relationships between cerebrospinal fluid amyloid-beta 42, tau, and p-tau levels. Alzheimer's Res Ther. 2018. doi:10.1186/s13195-018-0410-y

11. Deming Y, Li Z, Kapoor M, Harari O, Del-Aguila JL, Black K, et al. Genome-wide association study identifies four novel loci associated with Alzheimer's endophenotypes and disease modifiers. Acta Neuropathol. 2017. doi:10.1007/s00401-017-1685-y

12. $Q Y, K N, J L D-A, X W, S L R, K H ~ F$, et al. Genome-wide association study of brain amyloid deposition as measured by Pittsburgh Compound-B (PiB)-PET imaging. Mol Psychiatry. 2021;26: 309-321. doi:10.1038/S41380-018-0246-7

13. Caselli RJ, Graff-Radford NR, Reiman EM, Weaver A, Osborne D, Lucas J, et al. Preclinical memory decline in cognitively normal apolipoprotein $\mathrm{E}-\varepsilon 4$ homozygotes. Neurology. 1999. doi:10.1212/wnl.53.1.201

14. Belloy ME, Eger SJ, Le Guen Y, Napolioni V, Deters KD, Yang HS, et al. KL*VS heterozygosity reduces brain amyloid in asymptomatic at-risk APOE $* 4$ carriers. Neurobiol 
medRxiv preprint doi: https://doi.org/10.1101/2021.10.07.21264646; this version posted October 10, 2021. The copyright holder for this preprint (which was not certified by peer review) is the author/funder, who has granted medRxiv a license to display the preprint in perpetuity. All rights reserved. No reuse allowed without permission.

Aging. 2021. doi:10.1016/j.neurobiolaging.2021.01.008

15. Erickson CM, Schultz SA, Oh JM, Darst BF, Ma Y, Norton D, et al. KLOTHO heterozygosity attenuates APOE4-related amyloid burden in preclinical AD. Neurology. 2019. doi:10.1212/WNL.0000000000007323

16. Château MT, Araiz C, Descamps S, Galas S. Klotho interferes with a novel FGFsignalling pathway and insulin/lgf-like signalling to improve longevity and stress resistance in Caenorhabditis elegans. Aging (Albany NY). 2010. doi:10.18632/aging.100195

17. Kurosu H, Yamamoto M, Clark JD, Pastor J V, Nandi A, Gurnani P, et al. Suppression of Aging in Mice by. Science (80- ). 2005.

18. Dubal DB, Yokoyama JS, Zhu L, Broestl L, Worden K, Wang D, et al. Life Extension Factor Klotho Enhances Cognition. Cell Rep. 2014. doi:10.1016/j.celrep.2014.03.076

19. Leon J, Moreno AJ, Garay BI, Chalkley RJ, Burlingame AL, Wang D, et al. Peripheral Elevation of a Klotho Fragment Enhances Brain Function and Resilience in Young, Aging, and a-Synuclein Transgenic Mice. Cell Rep. 2017. doi:10.1016/j.celrep.2017.07.024

20. Arking DE, Krebsova A, Macek M, Macek M, Arking A, Mian IS, et al. Association of human aging with a functional variant of klotho. Proc Natl Acad Sci U S A. 2002. doi:10.1073/pnas.022484299

21. Yokoyama JS, Sturm VE, Bonham LW, Klein E, Arfanakis K, Yu L, et al. Variation in longevity gene KLOTHO is associated with greater cortical volumes. Ann Clin Transl Neurol. 2015. doi:10.1002/acn3.161

22. Arking DE, Atzmon G, Arking A, Barzilai N, Dietz HC. Association between a functional variant of the KLOTHO gene and high-density lipoprotein cholesterol, blood pressure, stroke, and longevity. Circ Res. 2005. doi:10.1161/01.RES.0000157171.04054.30

23. Braskie MN, Ringman JM, Thompson PM. Neuroimaging measures as endophenotypes in Alzheimer's disease. International Journal of Alzheimer's Disease. 2011. doi:10.4061/2011/490140

24. Farias FHG, Benitez BA, Cruchaga C. Quantitative endophenotypes as an alternative approach to understanding genetic risk in neurodegenerative diseases. Neurobiology of Disease. 2021. doi:10.1016/j.nbd.2020.105247

25. Li Z, Farias FHG, Dube U, Del-Aguila JL, Mihindukulasuriya KA, Fernandez MV, et al. The TMEM106B FTLD-protective variant, rs1990621, is also associated with increased neuronal proportion. Acta Neuropathol. 2020. doi:10.1007/s00401-019-02066-0

26. Deming Y, Filipello F, Cignarella F, Cantoni C, Hsu S, Mikesell R, et al. The MS4A gene cluster is a key modulator of soluble TREM2 and Alzheimer's disease risk. Sci Transl Med. 2019. doi:10.1126/scitransImed.aau2291

27. Porter T, Burnham SC, Milicic L, Savage G, Maruff P, Lim YY, et al. Klotho allele status is not associated with $A \beta$ and APOE $\varepsilon 4-$ related cognitive decline in preclinical Alzheimer's disease. Neurobiol Aging. 2019. doi:10.1016/j.neurobiolaging.2018.12.014

28. Dube U, Del-Aguila JL, Li Z, Budde JP, Jiang S, Hsu S, et al. An atlas of cortical circular RNA expression in Alzheimer disease brains demonstrates clinical and pathological associations. Nat Neurosci. 2019. doi:10.1038/s41593-019-0501-5 
medRxiv preprint doi: https://doi.org/10.1101/2021.10.07.21264646; this version posted October 10, 2021. The copyright holder for this preprint

(which was not certified by peer review) is the author/funder, who has granted medRxiv a license to display the preprint in perpetuity.

All rights reserved. No reuse allowed without permission.

29. Suárez-Calvet M, Morenas-Rodríguez E, Kleinberger G, Schlepckow K, Caballero MÁA, Franzmeier N, et al. Early increase of CSF sTREM2 in Alzheimer's disease is associated with tau related-neurodegeneration but not with amyloid- $\beta$ pathology. Mol Neurodegener. 2019. doi:10.1186/s13024-018-0301-5

30. Chang CC, Chow CC, Tellier LCAM, Vattikuti S, Purcell SM, Lee JJ. Second-generation PLINK: Rising to the challenge of larger and richer datasets. Gigascience. 2015. doi:10.1186/s13742-015-0047-8

31. Delaneau O, Marchini J, McVeanh GA, Donnelly P, Lunter G, Marchini JL, et al. Integrating sequence and array data to create an improved 1000 Genomes Project haplotype reference panel. Nat Commun. 2014. doi:10.1038/ncomms4934

32. Howie B, Fuchsberger C, Stephens M, Marchini J, Abecasis GR. Fast and accurate genotype imputation in genome-wide association studies through pre-phasing. Nat Genet. 2012. doi:10.1038/ng.2354

33. Team RC. R core team (2014). R A Lang Environ Stat Comput R Found Stat Comput Vienna, Austria URL http//www R-project org. 2014.

34. Lo MT, Kauppi K, Fan CC, Sanyal N, Reas ET, Sundar VS, et al. Identification of genetic heterogeneity of Alzheimer's disease across age. Neurobiol Aging. 2019.

doi:10.1016/j.neurobiolaging.2019.02.022

35. Blennow K, Mattsson N, Schöll M, Hansson O, Zetterberg H. Amyloid biomarkers in Alzheimer's disease. Trends Pharmacol Sci. 2015. doi:10.1016/j.tips.2015.03.002

36. Palmqvist S, Mattsson N, Hansson O. Cerebrospinal fluid analysis detects cerebral amyloid- $\beta$ accumulation earlier than positron emission tomography. Brain. 2016. doi:10.1093/brain/aww015

37. De Wilde A, Reimand J, Teunissen CE, Zwan M, Windhorst AD, Boellaard R, et al. Discordant amyloid- $\beta$ PET and CSF biomarkers and its clinical consequences.

Alzheimer's Res Ther. 2019. doi:10.1186/s13195-019-0532-x

38. Caselli RJ, Reiman EM. Characterizing the preclinical stages of Alzheimer's disease and the prospect of presymptomatic intervention. Journal of Alzheimer's Disease. 2013. doi:10.3233/JAD-2012-129026

39. Jadhav S, Avila J, Schöll M, Kovacs GG, Kövari E, Skrabana R, et al. A walk through tau therapeutic strategies. Acta neuropathologica communications. 2019. doi:10.1186/s40478-019-0664-z

40. Driscoll I, Ma Y, Gallagher CL, Johnson SC, Asthana S, Hermann BP, et al. Age-related tau burden and cognitive deficits are attenuated in Klotho KL-vs heterozygotes. J Alzheimer's Dis. 2021. doi:10.3233/JAD-200944

41. Neitzel J, Franzmeier N, Rubinski A, Dichgans M, Brendel M, Weiner M, et al. KL-VS heterozygosity is associated with lower amyloid-dependent tau accumulation and memory impairment in Alzheimer's disease. Nat Commun. 2021. doi:10.1038/s41467021-23755-z

42. Zeldich E, Chen C Di, Colvin TA, Bove-Fenderson EA, Liang J, Tucker Zhou TB, et al. The neuroprotective effect of Klotho is mediated via regulation of members of the redox system. J Biol Chem. 2014. doi:10.1074/jbc.M114.567321 
medRxiv preprint doi: https://doi.org/10.1101/2021.10.07.21264646; this version posted October 10, 2021. The copyright holder for this preprint

(which was not certified by peer review) is the author/funder, who has granted medRxiv a license to display the preprint in perpetuity.

All rights reserved. No reuse allowed without permission.

43. Neu SC, Pa J, Kukull W, Beekly D, Kuzma A, Gangadharan P, et al. Apolipoprotein E genotype and sex risk factors for Alzheimer disease: A meta-analysis. JAMA Neurol. 2017. doi:10.1001/jamaneurol.2017.2188

44. Farrer LA, Cupples LA, Haines JL, Hyman B, Kukull WA, Mayeux R, et al. Effects of age, sex, and ethnicity on the association between apolipoprotein $E$ genotype and Alzheimer disease. A meta-analysis. APOE and Alzheimer Disease Meta Analysis Consortium. JAMA. 2014.

45. Bickeböller H, Campion D, Brice A, Amouyel P, Hannequin D, Didierjean O, et al. Apolipoprotein E and Alzheimer disease: Genotype-specific risks by age and sex. Am J Hum Genet. 1997.

46. Invidia L, Salvioli S, Altilia S, Pierini M, Panourgia MP, Monti D, et al. The frequency of Klotho KL-VS polymorphism in a large Italian population, from young subjects to centenarians, suggests the presence of specific time windows for its effect.

Biogerontology. 2010. doi:10.1007/s10522-009-9229-z

47. Dubal DB, Zhu L, Sanchez PE, Worden K, Broestl L, Johnson E, et al. Life extension factor klotho prevents mortality and enhances cognition in hAPP transgenic mice. J Neurosci. 2015. doi:10.1523/JNEUROSCI.5791-12.2015 
medRxiv preprint doi: https://doi.org/10.1101/2021.10.07.21264646; this version posted October 10, 2021. The copyright holder for this preprint (which was not certified by peer review) is the author/funder, who has granted medRxiv a license to display the preprint in perpetuity. All rights reserved. No reuse allowed without permission.

Figure 1: Schematic overview of datasets and performed analysis.

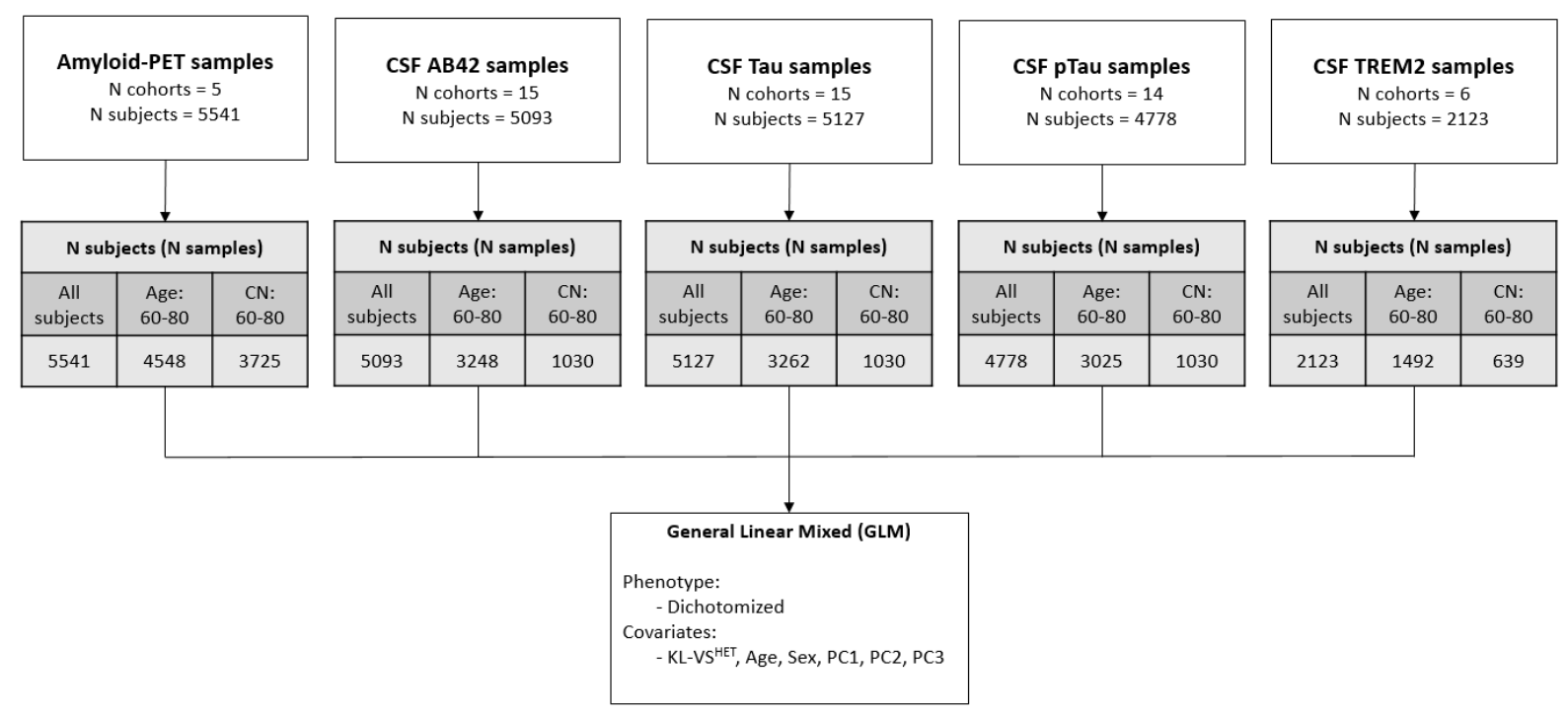

Schematic overview of datasets and performed analysis. Number of subjects in each modality were stratified into three categories: 1) All of the subjects; 2) Age: $60-80$, Subjects aged 60 to 80 years; 3 ) CN: $60-80$, Control subjects aged 60 to 80 years. Association between KL-VS ${ }^{\mathrm{HET}}$ and endophenotypes were assessed using multiple linear regression model for dichotomized phenotype. Age, Sex, and first three genetic PCs were used as covariates in an APOE4-stratified analysis. Abbreviations: PET, positron emission tomography; N, number of; CSF, cerebrospinal fluid; $A \beta$, $\beta$-amyloid; pTau, phosphorylated tau; CN, controls; KL, Klotho; Het, heterozygous; PC, principal component. 
Figure2: Forest plot of odds ratio (OR) for $\mathrm{KL}-\mathrm{VS}^{\mathrm{HET}+}$ association with dichotomized $\mathrm{AD}$ endophenotypes in 60-80 year control subjects, stratified by APOE4 status.
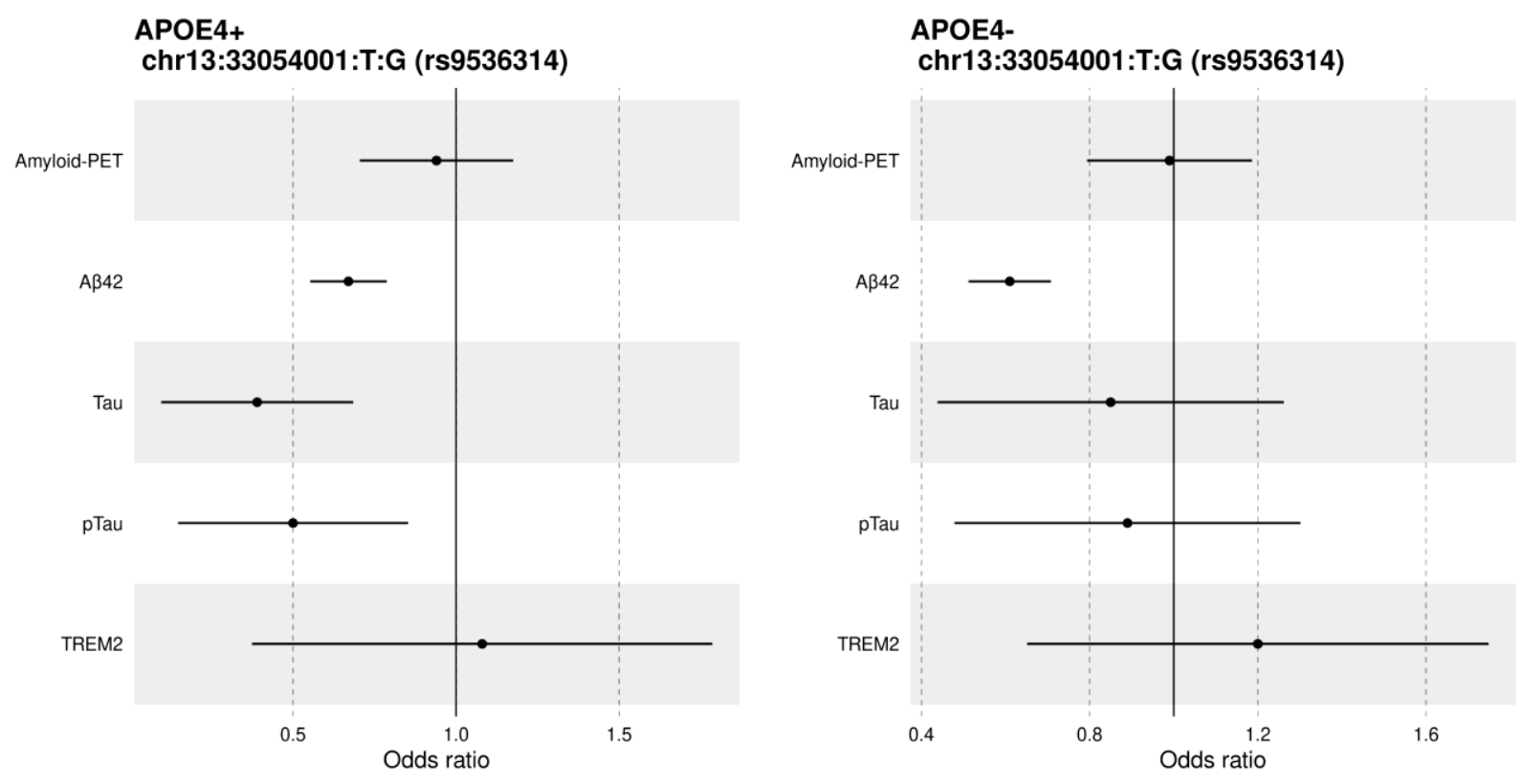

A significant association was detected between $\mathrm{KL}-\mathrm{VS}^{\mathrm{HET}+}$ and dichotomized A , Tau, and pTau CSF levels. In case of $A \beta$, the associations ware deemed significant across both APOE strata, whereas for Tau and pTau, associations were observed only in APOE4 carriers, representing an exclusive protective effect of KL-VSHET+ for the cognitively normal individuals who are aged 60 to 80 years and carrying APOE4. Abbreviations: APOE4+, Apolipoprotein E4 positive; APOE4-, Apolipoprotein E4 negative; PET, positron emission tomography; A $\beta$, $\beta$-amyloid; pTau, phosphorylated tau. 
medRxiv preprint doi: https://doi.org/10.1101/2021.10.07.21264646; this version posted October 10, 2021. The copyright holder for this preprint (which was not certified by peer review) is the author/funder, who has granted medRxiv a license to display the preprint in perpetuity.

Figure S1. KL-VS heterozygosity status is associated with CSF amyloid beta levels in cognitively normal individuals.

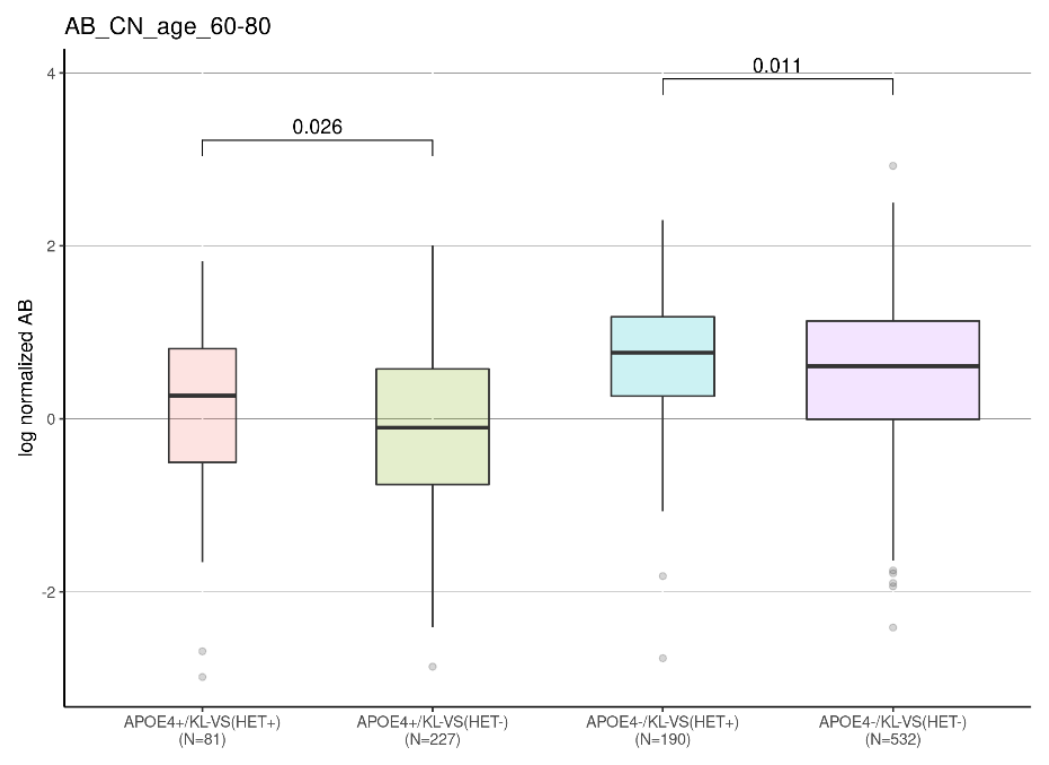

A significant association was detected between Klotho-VS ${ }^{\mathrm{HET}+}$ and dichotomized CSF amyloid beta (A $\left.\beta\right)$ levels. The distribution of quantitative log-normalized CSF A $\beta$ levels are shown in this box plot, stratified by APOE4 and KL-VS ${ }^{\mathrm{HET}+}$ status, where width of the boxplot represents the sample size of each group. Box plot error bars show the 95thpercentile range. Gray circles indicate values outside of the 95th percentile range. There is a significant difference between the means of compared groups (APOE4+/ KL-VS ${ }^{\mathrm{HET}+}$ vs. APOE4+/ $\mathrm{KL}-\mathrm{VS}^{\mathrm{HET}}$ - and APOE4-/ $\mathrm{KL}^{-\mathrm{VS}} \mathrm{HET}^{\mathrm{H}}$ vs. APOE4-/ KL-VS ${ }^{\mathrm{HET}-}$ ) with mean comparison p-values labelled on the top. Abbreviations: APOE4+, Apolipoprotein E4 positive; KL-VS ${ }^{\mathrm{HET}+}$, Klotho-VS heterozygous; KL-VS ${ }^{\mathrm{HET}-}$, Klotho-VS homozygous; N, number of samples. 
medRxiv preprint doi: https://doi.org/10.1101/2021.10.07.21264646; this version posted October 10, 2021. The copyright holder for this preprint (which was not certified by peer review) is the author/funder, who has granted medRxiv a license to display the preprint in perpetuity. All rights reserved. No reuse allowed without permission.

Figure S2: First two principal components of the genetic population structure across 17 cohorts together with the reference HapMap data (CEU, JPT, and YRI).

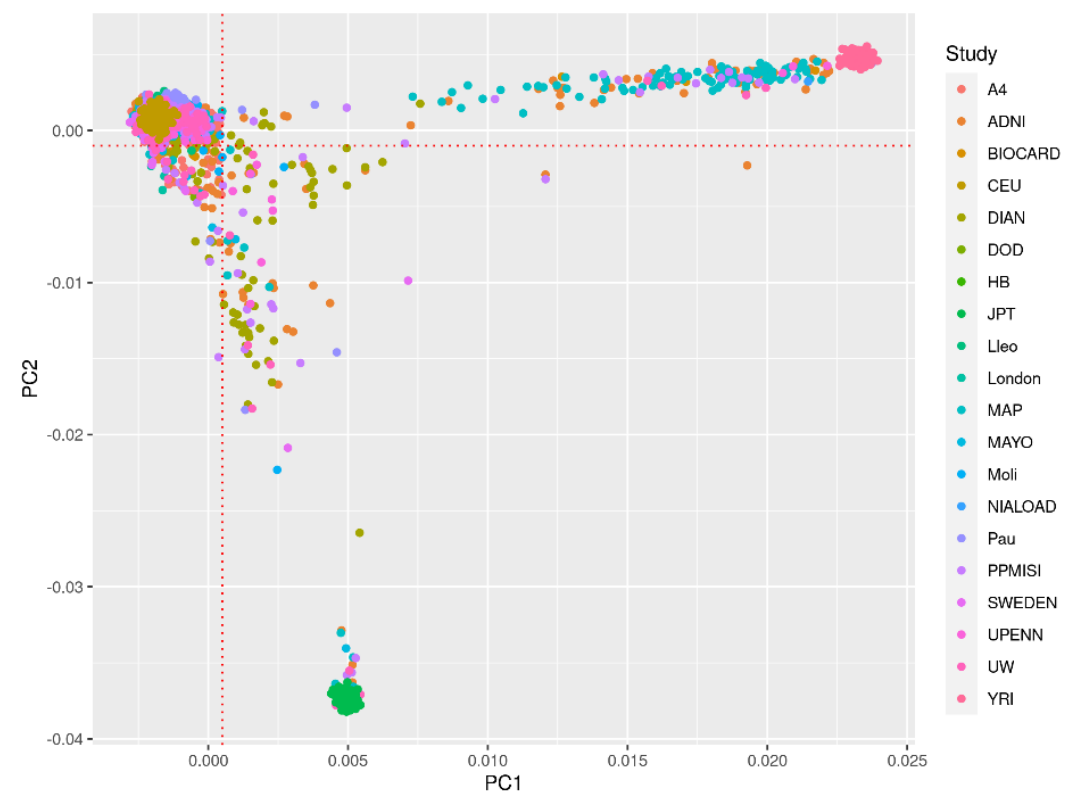

First two principal components of the genetic population structure across 17 cohorts (A4, ADNI, BIOCARD, DIAN, DOD, HB, Lleo, London, MAP, MAYO, Moli, NIALOAD, Pau, PPMISI, SWEDEN, UPENN, and UW) analyzed in this study, together with reference HapMap data (CEU, JPT, and YRI). The red dotted lines represent the thresholds (PC1 < 0.0005 and PC2 > -0.0010) for defining 9526 Northwestern European subjects. Abbreviations: PC, principal component. 
medRxiv preprint doi: https://doi.org/10.1101/2021.10.07.21264646; this version posted October 10, 2021. The copyright holder for this preprint (which was not certified by peer review) is the author/funder, who has granted medRxiv a license to display the preprint in perpetuity.

All rights reserved. No reuse allowed without permission.

Figure S3: First three principal components of the genetic population structure in Northwestern European subjects across all 17 cohorts.
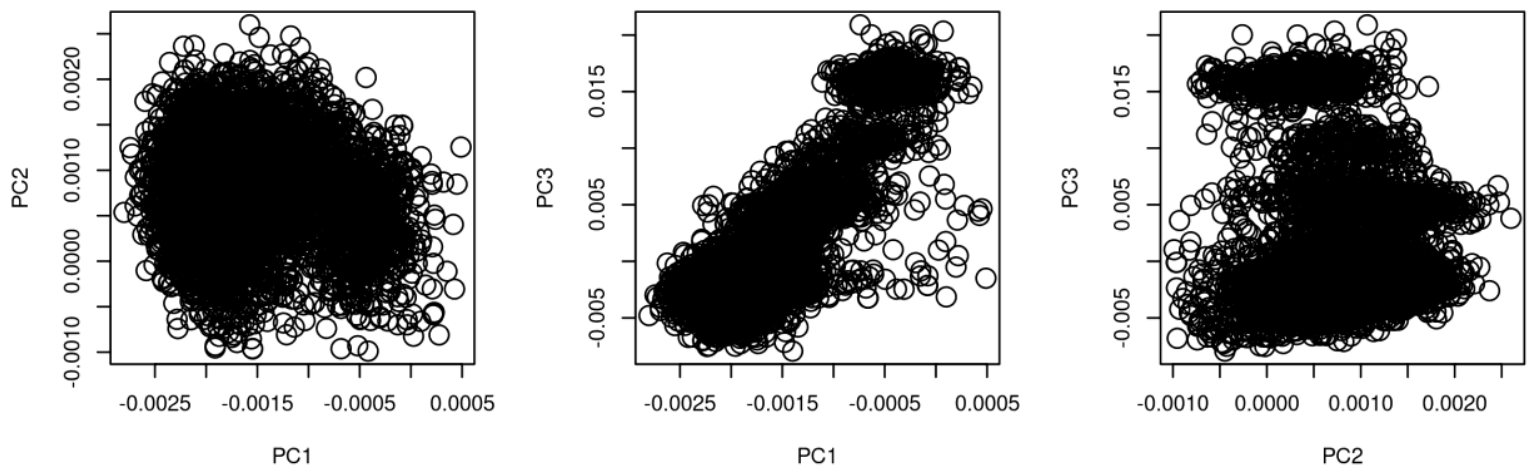

First three principal components (PCs) of the genetic population structure across 17 cohorts (A4, ADNI, BIOCARD, DIAN, DOD, HB, Lleo, London, MAP, MAYO, Moli, NIALOAD, Pau, PPMI, SWEDEN, UPENN, and UW) analyzed in this study. Abbreviations: PC, principal component. 
medRxiv preprint doi: https://doi.org/10.1101/2021.10.07.21264646; this version posted October 10, 2021. The copyright holder for this preprint (which was not certified by peer review) is the author/funder, who has granted medRxiv a license to display the preprint in perpetuity.

All rights reserved. No reuse allowed without permission.

Table 1. Demographics of analyzed Alzheimer's disease (AD) endophenotypes.

\begin{tabular}{|c|c|c|c|c|c|c|}
\hline & Total & $\begin{array}{l}\text { Amyloid- } \\
\text { PET }\end{array}$ & $A \beta 42$ & Tau & pTau & TREM2 \\
\hline Sample size & 9,526 & 5,541 & 5,093 & 5,127 & 4,778 & 2,123 \\
\hline Female (\%) & 51.86 & 54.54 & 49.30 & 49.19 & 48.68 & 50.31 \\
\hline Age, mean (SD) & $68.93(11.13)$ & $69.53(10.73)$ & $67.04(13.27)$ & $67.15(13.30)$ & $66.93(13.43)$ & $68.17(12.13)$ \\
\hline APOE4+ (\%) & 39.03 & 37.39 & 40.74 & 41.08 & 39.47 & 42.11 \\
\hline Biomarker, mean (SD) & $0.028(0.02)$ & $0.045(1.03)$ & $-0.0018(1)$ & $0.027(1)$ & $0.02(1)$ & $0.05(0.98)$ \\
\hline Klotho-VS ${ }^{\mathrm{HET}+}(\%)$ & 25.76 & 25.99 & 25.31 & 25.16 & 25.09 & 25.20 \\
\hline Cases & 3,109 & 1,090 & 2,424 & 2,443 & 2,297 & 1,074 \\
\hline Controls & 5,286 & 4,117 & 1,584 & 1,589 & 1,582 & 879 \\
\hline
\end{tabular}

Demographics of subjects at the time of amyloid PET imaging and CSF sampling. This table summarizes basic demographic information of subjects included in the analysis. For each modality, we report percentage of females, mean age of the subjects and standard deviation (SD) in the age, percentage of $A P O E 4+$ subjects, mean value of the endophenotypic biomarker and its SD, percentage of KL-VS heterozygous (KL-VS ${ }^{\mathrm{HET}+}$ ) subjects, and number of cases and controls. To normalize endophenotypes across different cohorts, we converted different amyloid imaging measures (e.g. Centiloid, PiB, and AV45) into log-normalized z-score using "scale" function in base R. Phenotype from each cohort was normalized individually to account for within cohort variation. These AD endophenotypes are used for checking their association with $\mathrm{KL}^{-V S}{ }^{\mathrm{HET}}+$. Abbreviations: PET, positron emission tomography; $A \beta, \beta-$ amyloid; pTau, phosphorylated tau; soluble triggering receptor expressed on myeloid cells 2, TREM2; sd, standard deviation; KL-VS, Klotho-VS; Het+, heterozygosity. 
medRxiv preprint doi: https://doi.org/10.1101/2021.10.07.21264646; this version posted October 10, 2021. The copyright holder for this preprint

(which was not certified by peer review) is the author/funder, who has granted medRxiv a license to display the preprint in perpetuity.

All rights reserved. No reuse allowed without permission.

Table 2. Genetic association of KL-VSHET+ with AD endophenotypes in cognitively normal subjects aged $60-80$ years, stratified by APOE4 status.

\begin{tabular}{|c|c|c|c|c|c|}
\hline Modality & Group & $\begin{array}{l}\text { CN subjects } \\
\text { (KL-VS } \\
\text { HET+ \%) }\end{array}$ & Odds ratio & Estimate & $P$ value \\
\hline \multirow{2}{*}{ Amyloid PET } & APOE4+ & $1328(27.5)$ & 0.94 & -0.07 & 0.61 \\
\hline & APOE4- & 2397 (26.5) & 0.99 & -0.01 & 0.90 \\
\hline \multirow{2}{*}{$A \beta 42$} & APOE4+ & $308(26.3)$ & 0.67 & 0.72 & 0.007 \\
\hline & APOE4- & $722(26.3)$ & 0.61 & 0.46 & 0.03 \\
\hline \multirow{2}{*}{ Tau } & APOE4+ & 308 (26.9) & 0.39 & -0.94 & 0.007 \\
\hline & APOE4- & $722(26.5)$ & 0.85 & -0.16 & 0.49 \\
\hline \multirow{2}{*}{ pTau } & APOE4+ & $308(26.9)$ & 0.50 & -0.68 & 0.04 \\
\hline & APOE4- & $722(26.3)$ & 0.89 & -0.11 & 0.61 \\
\hline \multirow{2}{*}{ TREM2 } & APOE4+ & $199(31.2)$ & 1.08 & 0.08 & 0.80 \\
\hline & APOE4- & $440(25.2)$ & 1.20 & 0.18 & 0.43 \\
\hline
\end{tabular}

Association between $\mathrm{KL}-\mathrm{VS} \mathrm{HET}^{\mathrm{H}}$ and different dichotomized $\mathrm{AD}$ endophenotypes were assessed using general linear model (GLM). We used dichotomized endophenotype as the response variable, whereas, age, sex, and first three genetic PCs were used as covariates in an APOE4-stratified analysis. Significant associations are represented by bold P-values. Abbreviations: KL-VS ${ }^{\mathrm{HET}}$, Klotho-VS heterozygous; CN, Control; AD, Alzheimer's disease; Std. Error, Standard error; \%, percentage; $A \beta, \beta$-amyloid; $p$ Tau, phosphorylated tau; soluble triggering receptor expressed on myeloid cells 2, TREM2. 
medRxiv preprint doi: https://doi.org/10.1101/2021.10.07.21264646; this version posted October 10, 2021. The copyright holder for this preprint (which was not certified by peer review) is the author/funder, who has granted medRxiv a license to display the preprint in perpetuity.

All rights reserved. No reuse allowed without permission.

Table S1. Demographic characteristics for each analyzed cohort.

\begin{tabular}{|c|c|c|c|c|c|c|c|c|c|c|c|c|c|c|c|}
\hline \multirow{2}{*}{$\begin{array}{l}\text { Cohort } \\
\text { name }\end{array}$} & \multicolumn{3}{|c|}{ Participants } & \multicolumn{3}{|c|}{ Diagnosis \% (AD/CN) } & \multicolumn{3}{|c|}{ Age, mean (sd) } & \multicolumn{3}{|c|}{ Sex \% (F/M) } & \multicolumn{3}{|c|}{ APOE4+ (\%) } \\
\hline & All & $60-80$ & CN & All & $60-80$ & $\mathrm{CN}$ & All & $60-80$ & CN & All & $60-80$ & $\mathrm{CN}$ & All & $60-80$ & $\mathrm{CN}$ \\
\hline MAP & 1323 & 954 & 565 & $27 / 61$ & $29 / 59$ & $0 / 100$ & $70(10)$ & $71(5)$ & $70(5)$ & $54 / 46$ & $53 / 47$ & $55 / 45$ & 41 & 44 & 35 \\
\hline NIALOAD & 24 & 15 & 14 & $17 / 79$ & 7/93 & $0 / 100$ & 74 (9) & $72(5)$ & $71(5)$ & $62 / 38$ & $60 / 40$ & $57 / 43$ & 21 & 27 & 29 \\
\hline ADNI & 1734 & 1368 & 401 & $63 / 27$ & $61 / 29$ & $0 / 100$ & $74(7)$ & $72(5)$ & $71(5)$ & $45 / 55$ & $46 / 54$ & $56 / 44$ & 44 & 46 & 29 \\
\hline BIOCARD & 215 & 97 & 53 & $0 / 69$ & $0 / 55$ & $0 / 100$ & $58(10)$ & $65(5)$ & $64(4)$ & $60 / 40$ & $53 / 47$ & $60 / 40$ & 33 & 30 & 26 \\
\hline DIAN & 411 & 17 & - & $8 / 6$ & $0 / 0$ & - & 39 (11) & $63(3)$ & - & $56 / 44$ & $53 / 47$ & - & 30 & 41 & - \\
\hline HB & 102 & 71 & - & $100 / 0$ & $100 / 0$ & - & $68(9)$ & $70(6)$ & - & $45 / 55$ & $2 / 58$ & - & 53 & 56 & - \\
\hline Lleo & 137 & 81 & 39 & $36 / 64$ & $52 / 48$ & $0 / 100$ & $64(10)$ & $70(6)$ & 68 (4) & $65 / 35$ & $64 / 36$ & $64 / 36$ & 36 & 41 & 31 \\
\hline London & 249 & 192 & 18 & $27 / 8$ & $26 / 9$ & $0 / 100$ & $69(9)$ & $70(6)$ & 65 (4) & $46 / 54$ & $46 / 54$ & $28 / 72$ & 47 & 44 & 33 \\
\hline Moli & 232 & 155 & 31 & $56 / 22$ & $56 / 20$ & $0 / 100$ & $65(8)$ & $68(6)$ & $68(6)$ & $63 / 37$ & $59 / 41$ & $39 / 61$ & 37 & 37 & 16 \\
\hline Pau & 143 & 106 & - & $12 / 0$ & $12 / 0$ & - & $67(9)$ & $70(5)$ & - & $50 / 50$ & $47 / 53$ & - & 36 & 35 & - \\
\hline MAYO & 400 & 219 & 181 & $6 / 76$ & $4 / 83$ & $0 / 100$ & $79(6)$ & $76(3)$ & $76(3)$ & $38 / 62$ & $42 / 58$ & $43 / 57$ & 28 & 31 & 27 \\
\hline SWEDEN & 284 & 194 & - & $0 / 0$ & $0 / 0$ & - & $75(8)$ & $74(5)$ & - & $63 / 37$ & $58 / 42$ & - & 76 & 77 & - \\
\hline UPENN & 113 & 80 & - & $0 / 0$ & $0 / 0$ & - & $72(9)$ & $72(5)$ & - & $58 / 42$ & $51 / 49$ & - & 58 & 68 & - \\
\hline UW & 355 & 197 & - & $0 / 0$ & $0 / 0$ & - & $63(16)$ & $70(6)$ & - & $50 / 50$ & $49 / 51$ & - & 43 & 48 & - \\
\hline PPMISI & 546 & 316 & 87 & $0 / 29$ & 0/28 & $0 / 100$ & $62(10)$ & $68(5)$ & $68(5)$ & $33 / 67$ & $29 / 71$ & $28 / 72$ & 27 & 25 & 26 \\
\hline A4 & 3106 & 2935 & 2934 & $0 / 100$ & $0 / 100$ & $0 / 100$ & 71 (5) & $71(4)$ & $71(4)$ & $60 / 40$ & $61 / 39$ & $61 / 39$ & 36 & 37 & 37 \\
\hline ADNIDOD & 152 & 147 & 98 & $32 / 68$ & $33 / 67$ & $0 / 100$ & $69(5)$ & $69(4)$ & $69(4)$ & $1 / 99$ & $1 / 99$ & $1 / 99$ & 27 & 27 & 30 \\
\hline
\end{tabular}

Demographics of subjects at the time of amyloid PET imaging and CSF sampling across each cohort. This table summarizes the demographic characteristics of participants for each analyzed cohort. Participant stratification was performed at three levels, 1) All, All of the subjects; 2) $60-80$, Subjects that are 60 to 80 years old; 3) CN, Subjects that are controls and aged 60 to 80 years. For each cohort, we report number of subjects in each stratum, their diagnosis (number of AD and controls subjects), mean age of the participants and standard deviation in the age across cohort, percentage of females and males, and percentage of APOE4+ subjects. Abbreviations: \%, percentage; AD, Alzheimer's Disease; CN, Controls; sd, standard deviation; F, Females; M, Males; APOE4+, Apolipoprotein E4 positive; All, All participating subjects (controls and AD); 60-80: Participating subjects aged 60-80 (controls and AD); CN: 60-80, Control participating subjects aged 60-80; MAP, Memory and Aging Project (MAP); NIALOAD, National Institute on Aging Late Onset Alzheimer's Disease; ADNI, Alzheimer's Disease Neuroimaging Initiative; BIOCARD; DIAN, the Dominantly Inherited Alzheimer Network; HB; Lleo; London; MOLI; Pau; MAYO, Mayo Clinic; SWEDEN; UPENN; UW; PPMI, Progression Markers Initiative; A4, Anti-Amyloid Treatment in Asymptomatic Alzheimer's Disease; ADNIDOD, ADNI Department of Defense. 
medRxiv preprint doi: https://doi.org/10.1101/2021.10.07.21264646; this version posted October 10, 2021. The copyright holder for this preprint (which was not certified by peer review) is the author/funder, who has granted medRxiv a license to display the preprint in perpetuity.

All rights reserved. No reuse allowed without permission.

Table S2. Genetic association of $\mathrm{KL}-\mathrm{VS}^{\mathrm{HET}+}$ with dichotomized AD endophenotypes (GLM), stratified by APOE4 status.

\begin{tabular}{|c|c|c|c|c|c|}
\hline Modality & Group & $\begin{array}{l}\text { CN/AD subjects } \\
\left.\text { (KL-VS }{ }^{H E T+\%} \%\right)\end{array}$ & Odds ratio & Estimate & $P$ value \\
\hline & All subjects & & & & \\
\hline & APOE4+ & 1432/526 (27.2/24) & 0.89 & -0.12 & 0.26 \\
\hline & $\begin{array}{l}\text { APOE4- } \\
\text { Age 60-80 }\end{array}$ & $2685 / 564(26.4 / 25.5)$ & 1.02 & 0.02 & 0.85 \\
\hline \multirow[t]{8}{*}{ Amyloid PET } & APOE4+ & $1328 / 421(27.5 / 25.9)$ & 0.87 & -0.14 & 0.23 \\
\hline & APOE4- & $2397 / 371(26.5 / 26.1)$ & 1.02 & 0.02 & 0.84 \\
\hline & CN: Age 60-80 & & & & \\
\hline & APOE4+ & 1328/NA (27.5/NA) & 0.94 & -0.07 & 0.61 \\
\hline & APOE4- & 2397/NA (26.5/NA) & 0.99 & -0.01 & 0.90 \\
\hline & All subjects & & & & \\
\hline & APOE4+ & 461/1076 (26.7/24.9) & 0.55 & 0.20 & 0.07 \\
\hline & $\begin{array}{l}\text { APOE4- } \\
\text { Age } 60-80\end{array}$ & $1123 / 1348(26.3 / 25.7)$ & 0.52 & 0.07 & 0.43 \\
\hline \multirow[t]{8}{*}{ AB42 } & APOE4+ & $308 / 814(26.3 / 25.9)$ & 0.56 & 0.24 & 0.08 \\
\hline & APOE4- & 722/921 (26.3/24.9) & 0.54 & 0.16 & 0.15 \\
\hline & CN: Age 60-80 & & & & \\
\hline & APOE4+ & $308 / \mathrm{NA}(26.3 / \mathrm{NA})$ & 0.67 & 0.72 & 0.007 \\
\hline & APOE4- & 722/NA (26.3/NA) & 0.61 & 0.46 & 0.03 \\
\hline & All subjects & & & & \\
\hline & APOE4+ & 465/1095 (27.3/24.7) & 1.07 & 0.07 & 0.51 \\
\hline & $\begin{array}{l}\text { APOE4- } \\
\text { Age } 60-80\end{array}$ & $1124 / 1348(26.3 / 25.3)$ & 0.86 & -0.11 & 0.27 \\
\hline \multirow[t]{7}{*}{ Tau } & APOE4+ & $308 / 828(26.9 / 25.6)$ & 1.02 & 0.02 & 0.89 \\
\hline & $\begin{array}{c}\text { APOE4- } \\
\text { CN: Age 60-80 }\end{array}$ & 722/920 (26.5/24.5) & 1.01 & 0.01 & 0.95 \\
\hline & APOE4+ & $308 / \mathrm{NA}(26.9 / \mathrm{NA})$ & 039 & 0 94 & \\
\hline & APOE4- & 722/NA (26.5/NA) & 0.85 & -0.16 & 0.49 \\
\hline & All subjects & & & & \\
\hline & APOE4+ & 465/1024 (27.3/24) & 0.96 & -0.04 & 0.73 \\
\hline & $\begin{array}{l}\text { APOE4- } \\
\text { Age 60-80 }\end{array}$ & 1117/1273 (26.2/25.3) & 0.98 & -0.02 & 0.88 \\
\hline \multirow[t]{8}{*}{ pTau } & APOE4+ & 308/779 (26.9/24.8) & 0.91 & -0.09 & 0.48 \\
\hline & APOE4- & 722/864 (26.3/24.5) & 1.04 & 0.04 & 0.76 \\
\hline & CN: Age 60-80 & & & & \\
\hline & APOE4+ & $308 / \mathrm{NA}(26.9 / \mathrm{NA})$ & 0.50 & -0.68 & 0.04 \\
\hline & APOE4- & 722/NA (26.3/NA) & 0.89 & -0.11 & 0.61 \\
\hline & All subjects & & & & \\
\hline & APOE4+ & $274 / 569(28.8 / 24.1)$ & 0.96 & -0.04 & 0.78 \\
\hline & $\begin{array}{l}\text { APOE4- } \\
\text { Age 60-80 }\end{array}$ & $605 / 505$ (25/27.5) & 0.89 & -0.11 & 0.42 \\
\hline \multirow[t]{5}{*}{ TREM2 } & APOE4+ & 199/469 (31.2/25.4) & 0.89 & -0.11 & 0.53 \\
\hline & APOE4- & 440/378 (25.2/26.2) & 0.99 & -0.01 & 0.96 \\
\hline & CN: Age $60-80$ & & & & \\
\hline & APOE4+ & 199/NA (31.2/NA) & 1.08 & 0.08 & 0.80 \\
\hline & APOE4- & 440/NA (25.2/NA) & 1.20 & 0.18 & 0.43 \\
\hline
\end{tabular}

Association between $\mathrm{KL}-\mathrm{VS} \mathrm{HET}^{\mathrm{HE}}$ and different dichotomized $\mathrm{AD}$ endophenotypes were assessed using general linear model (GLM). Association were assessed across three strata: 1) all subjects (controls and AD), 2) subjects aged 60-80 (controls and AD), and 3) cognitively normal subjects aged 60-80 years. We used dichotomized endophenotype as the response variable, whereas, age, sex, and first three genetic PCs were used as covariates 
medRxiv preprint doi: https://doi.org/10.1101/2021.10.07.21264646; this version posted October 10, 2021. The copyright holder for this preprint (which was not certified by peer review) is the author/funder, who has granted medRxiv a license to display the preprint in perpetuity. All rights reserved. No reuse allowed without permission.

in an APOE4-stratified analysis. Significant associations are represented by bold P-values. Abbreviations: KL$\mathrm{VS}^{\mathrm{HET}}$, Klotho-VS heterozygous; CN, Control; AD, Alzheimer's disease; Std. Error, Standard error; \%, percentage; $A \beta, \beta$-amyloid; $p$ Tau, phosphorylated tau; soluble triggering receptor expressed on myeloid cells 2 , TREM2. 
Table S3. Genetic association of KL-VS ${ }^{\mathrm{HET}+}$ with AD endophenotypes in cognitively normal ageand sex-matched subjects, stratified by APOE4 status.

\begin{tabular}{|c|c|c|c|c|c|}
\hline Modality & Group & $\begin{array}{c}\text { CN subjects } \\
\text { (KL-VS } \\
\text { HET+ \%) }\end{array}$ & Odds ratio & Estimate & $P$ value \\
\hline \multirow{2}{*}{ Amyloid PET } & APOE4+ & $1324(27.6)$ & 0.93 & -0.07 & 0.57 \\
\hline & APOE4- & $1324(25.5)$ & 0.95 & -0.05 & 0.72 \\
\hline \multirow{2}{*}{ Aß42 } & APOE4+ & 307 (26.1) & 0.68 & 0.75 & 0.005 \\
\hline & APOE4- & $307(26.1)$ & 0.67 & 0.70 & 0.03 \\
\hline \multirow{2}{*}{ Tau } & APOE4+ & 307 (26.7) & 0.39 & -0.93 & 0.008 \\
\hline & APOE4- & $307(26.1)$ & 0.49 & -0.71 & 0.11 \\
\hline \multirow{2}{*}{ pTau } & APOE4+ & $307(26.7)$ & 0.51 & -0.67 & 0.04 \\
\hline & APOE4- & $307(26.1)$ & 0.75 & -0.28 & 0.45 \\
\hline \multirow{2}{*}{ TREM2 } & APOE4+ & $192(29.7)$ & 1.15 & 0.14 & 0.66 \\
\hline & APOE4- & $192(23.4)$ & 1.08 & 0.08 & 0.82 \\
\hline
\end{tabular}

Association between $\mathrm{KL}-\mathrm{VS} \mathrm{HET}^{\mathrm{H}}$ and different dichotomized $\mathrm{AD}$ endophenotypes were assessed using general linear model (GLM). We used dichotomized endophenotype as the response variable, whereas, age, sex, and first three genetic PCs were used as covariates in an APOE4-stratified analysis. For each modality, we considered equal number of age- and sex-matched participants from both APOE4 strata. Significant associations are represented by bold P-values. Abbreviations: KL-VS ${ }^{\mathrm{HET}}$, Klotho-VS heterozygous; CN, Control; AD, Alzheimer's disease; Std. Error, Standard error; \%, percentage; $A \beta, \beta$-amyloid; $p$ Tau, phosphorylated tau; soluble triggering receptor expressed on myeloid cells 2, TREM2. 